\title{
MEASUREMENT OF LYCOPENE EFFECTIVENESS ON LUNG AND KIDNEY CANCER CELLS BY QUANTITATIVE 1H MAGNETIC RESONANCE IMAGING IN VITRO
}

\author{
ZUZANNA BOBER ${ }^{1}$, DAVID AEBISHER ${ }^{1}$, KATARZYNA POGODA², MARIA PUCKA ${ }^{2}$, \\ JACEK TABARKIEWICZ ${ }^{2}$ and DOROTA BARTUSIK-AEBISHER ${ }^{2,3 *}$
}

'Department of Photomedicine and Physical Chemistry, ${ }^{2}$ Centre for Innovative Research in Medical and Natural Sciences,

${ }^{3}$ Department of Biochemistry and General Chemistry, Medical College of The University of Rzeszow, Rzeszow, Poland

\begin{abstract}
This study aimed to utilize Magnetic Resonance Imaging (MRI) to monitor the effect of Lycopene on cultured cancer cells. Lycopene may be preventive against the development of cancer e.g. lung and kidney. The efficacy of lycopene $(2.5 \mu \mathrm{L} / \mathrm{mL}, 5.0 \mu \mathrm{L} / \mathrm{mL}$, and $20 \mu \mathrm{L} / \mathrm{mL})$ was examined using MRI. T1 relaxation time was measured prior to and after $24 \mathrm{~h}$ of treatment of lung cancer cell line A549 and kidney cancer cell line ACHN cells. The untreated cell lines (A549 and ACHN) were considered as a control. The study shows that T1 relaxation can be used for the non-invasive monitoring of cancer cells' death caused by Lycopene treatment. Lycopene may inhibit the growth of A549 and ACHN cell lines. After Lycopene treatment, we determine changes in spin-lattice relaxation in lung cancer cell line A549 and kidney cancer cell line ACHN.
\end{abstract}

Keywords: lycopene, magnetic resonance imaging, kidney cancer, lung cancer, cell cultures

Lycopene, a tetraterpene hydrocarbon containing 40 carbon atoms and 56 hydrogen atoms, is synthesized by plants and photosynthetic microorganisms. Lycopene is one of more than 600 carotenoids and is known as an antioxidant. In addition to this, according to literature reports, Lycopene has healthpromoting properties, and above all, helps to inhibit the development of cancer, reduces the risk of heart attack and improves resistance to infections (1). Sources of lycopene are fruits and vegetables. The most popular sources of lycopene are tomatoes, pink grapefruit, watermelon, rosehips, and apricots. Moreover, lycopene is the most abundant carotenoid in tomatoes (Lycopersicon esculentum L.) with concentrations ranging from $0.9-4.2 \mathrm{mg} / 100 \mathrm{~g}$ depending upon the variety (2). Oxidative stress is recognized as one of the major contributors to the increased risk of cancer. Oxidative stress in the body leads to the development of various types of diseases, including cancer, hence the need to consume substances with a strong antioxidant effect. Such health-promoting properties result from the use of
Lycopene. In addition, lycopene removes free radicals from the body that promote cancer development and this reduces the risk of cancer. The system of conjugated double bonds allows the lycopene molecule to efficiently quench a large spectrum of free radicals (3). A tomato-rich diet with high levels of Lycopene may lower the risk of certain types of cancers, including lung cancer (4). Moreover, increasing experimental studies have suggested that the lycopene molecule possesses anti-tumor activity in lung tumorigenesis (4). Numerous scientific studies have focused on the use of lycopene as an anti-cancer agent. The growth-inhibitory effects of lycopene were observed in lung cancer cells (5) prostate (6), breast (7), hepatoma (8), stomach (9), colon (10), and oral cancer cells (11). Our primary goal in this paper is to demonstrate the usefulness of quantitative MRI in lycopene pharmacology using high-density cancer cell cultures to study the effect of lycopene in vitro. The main reason for cellular studies was a lack of such as studies in the literature. To date, the influence of lycopene has been studied in

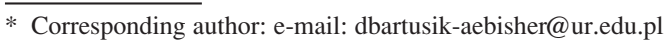


animal models, humans, and under in vitro conditions. However, no real comparison was possible due to differences in lycopene delivery and body metabolism in vivo. Several lycopene metabolites have been identified, raising the question as to whether the preventive effects of lycopene on cancer risk is, at least in part, due to its metabolites, although none have been confirmed. The use of Magnetic Resonance Imaging (MRI) can provide basic quantitative and qualitative information without additional sample preparation. Therefore, our interest in this study was to monitor viability changes in A549 and ACHN cancer cell lines by measurements of relaxation time which is correlated with targeted cell death.

\section{EXPERIMENTAL}

\section{Materials}

Cell culture

The cell lines used for this study were the A549 lung cancer cell line (American Type Culture Collection, VA, USA) and the ACHN renal cancer cell line (American Type Culture Collection, VA, USA). Cells were cultured under standard conditions: temperature $37^{\circ} \mathrm{C}, 5 \% \mathrm{CO}_{2}$ and $95 \%$ humidity. The culture medium consisted of Dulbecco's Modified Eagle's Medium (Sigma-Aldrich, MO, USA), Dulbecco's Modified Eagle's Medium Nutrient Mixture F-12 Ham (Sigma-Aldrich, MO, USA), Fetal Bovine Serum (Biochrom, Germany), and Penicillin-Streptomycin-Neomycin Solution Stabilized (Sigma-Aldrich, MO, USA). The culture of lung cancer cells was passaged on the 3rd day with the use of Accutase Cell Detachment Solution (Corning, NY, USA) to five $70 \mathrm{~mL}$ Tissue Culture Flasks (ThermoFisher Scientific, MA, USA). Lycopene $=90 \%$ was purchased from (SigmaAldrich, MO, USA). On the 7th day, cells were treated with different doses of lycopene $(2.5 \mu \mathrm{L} / \mathrm{mL}$, $5.0 \mu \mathrm{L} / \mathrm{mL}$ and $25 \mu \mathrm{L} / \mathrm{mL}$ ). Two other cell cultures served as negative controls - one with the addition of $5 \mu \mathrm{L}$ dimethyl sulfoxide (VWR, PA, USA) per $1 \mathrm{~mL}$ of culture medium and the second one without any supplements. Twenty four hours after treatment with lycopene (Sigma-Aldrich, MO, USA), the cells were treated with Accutase Cell Detachment Solution (Corning, NY, USA) and washed in Phosphate Buffered Saline Dulbecco without $\mathrm{Mg}^{2+}$ and $\mathrm{Ca}^{2+}$ (Biochrom, Germany). Cells were counted with the use of Muse Cell Analyzer (Merck Millipore, MA, USA). In the next step, samples were centrifuged ( $5 \mathrm{~min}$., $250 \times \mathrm{g}$ at room temperature) in $1.5 \mathrm{~mL}$ Eppendorf tubes (Eppendorf, Germany) and the supernatant from samples was discarded.

ACHN renal cancer cell line was cultured also in five $70 \mathrm{~mL}$ tissue culture flasks (ThermoFisher Scientific, MA, USA). Cells were treated with lycopene $(2.5 \mu \mathrm{L} / \mathrm{mL}, 5.0 \mu \mathrm{L} / \mathrm{mL}$, and $25 \mu \mathrm{L} / \mathrm{mL})$. After 24 hours of incubation with Lycopene (SigmaAldrich, MO, USA), cultures were treated with Accutase Cell Detachment Solution (Corning, NY, USA), and cells were counted with the use of Muse Cell Analyzer (Merck Millipore, MA, USA).

\section{MRI quantitative technique}

All MRI scans were performed with an Optima MR360 magnetic resonance apparatus from General Electric Healthcare (Milwaukee, Wisconsin, USA) supported in the SV23 software version. The prepared samples were placed in the MR tunnel and then a series of measurements were made to determine the relaxation times $T_{1}$. The lung and kidney cancer cells in the vials were placed on the FLEX Small transceiver coil. To perform the $\mathrm{T}_{1}$ measurements, the Fast Spin Echo (FSE) sequence was used with the following parameters: field of view (FOV) $=10 \times 10 \mathrm{~cm}$; matrix $=320 \times 224 ;$ NEX $=2.0$; slice thickness $=1.0 \mathrm{~mm}$; spacing $=0.5$ ). TR time varied in the range of $48-15000 \mathrm{~ms}$ with the following steps 48, 50, 100, 150, 200, 300, 500, 1000, 1500, 2000, 3000, 5000, 10000 and $15000 \mathrm{~ms}$. TE time was set up to $3 \mathrm{~ms}$. In the first step, measurements were taken to determine the relaxation times $T_{1}$ for Lycopene and DMSO then mixture Lycopene: DMSO (1:2) were combined and the relaxation times were again determined. In addition, to determine $T_{1}$ relaxation time and scans of tomato fruit (L. esculentum L.) were performed.

Table. 1. Results of T1 (ms) relaxation times for Lycopene solution, pure DMSO, Lycopene mixture with DMSO (Lycopene : DMSO 1:2), tomato fruit (L. esculentum L.) and water.

\begin{tabular}{|c|c|c|c|c|}
\hline $\begin{array}{c}\text { Lycopene } \\
(\mathrm{ms})\end{array}$ & $\begin{array}{c}\text { DMSO } \\
(\mathrm{ms})\end{array}$ & $\begin{array}{c}\text { Lycopene : DMSO (1 : 2) } \\
(\mathrm{ms})\end{array}$ & $\begin{array}{c}\text { Tomato fruit (L. esculentum L.) } \\
(\mathrm{ms})\end{array}$ & $\begin{array}{c}\mathrm{H}_{2} \mathrm{O} \\
(\mathrm{ms})\end{array}$ \\
\hline $2191 \pm 12$ & $2261 \pm 7$ & $2501 \pm 10$ & $1561 \pm 11$ & $3100 \pm 9$ \\
\hline
\end{tabular}

where (ms) is milisecunds. 


\section{Statistical analysis}

Differences between groups at each time-point were identified by one-way ANOVA.

\section{RESULTS AND DISCUSSION}

Lycopene is an extremely hydrophobic compound. To deliver lycopene to cells in the culture we

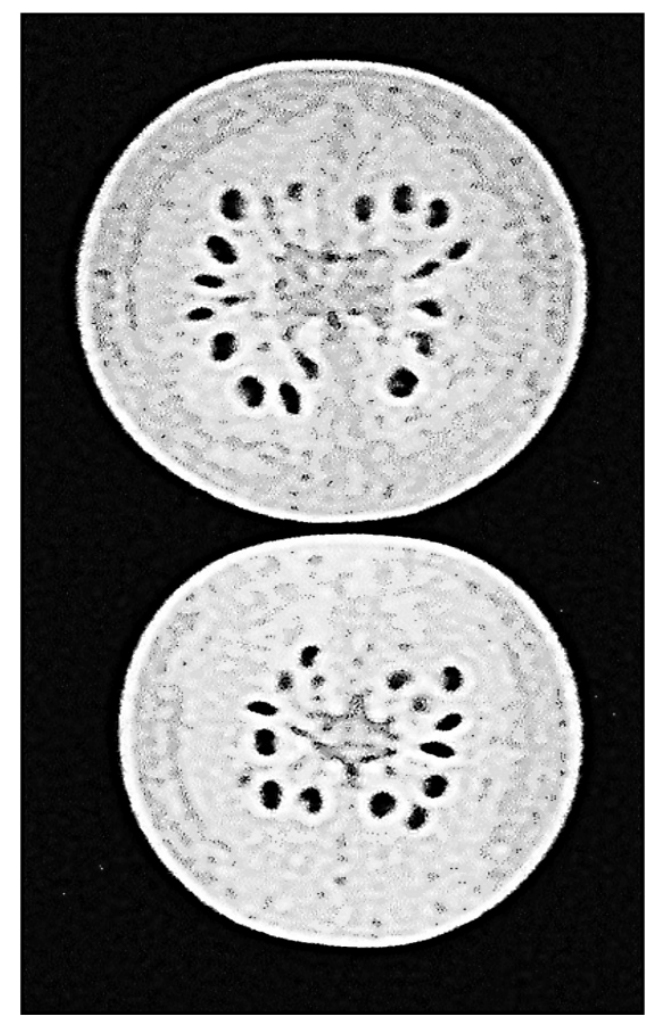

Figure 1. An MRI image of tomato fruit (L. esculentum L.) performed with Fast Spin Echo sequence and parameters TR $=12000$ $\mathrm{ms}$ and $\mathrm{TE}=10 \mathrm{~ms}$. included the use of organic solvents such as DMSO or fetal bovine serum. Table 1 presents the results of the relaxation times of pure solutions and tomato fruit pulp (L. esculentum L.). Figure 1 below shows images of tomato fruit (L. esculentum L.). The next stage of the study was to determine $\mathrm{T}_{1}$ relaxation times in lung cancer cells (A549 lung cancer cell line) and kidney cancer cells (ACHN renal cancer cell line) treated with lycopene in the following concentrations $(0 \mu \mathrm{L} / \mathrm{mL}, 2.5 \mu \mathrm{L} / \mathrm{mL}, 5.0 \mu \mathrm{L} / \mathrm{mL}$, and $20 \mu \mathrm{L} / \mathrm{mL}$ ) and in DMSO. The curves of the designated $\mathrm{T}_{1}$ relaxation times for lung cancer cells before and after treatment are shown in Figure 2. The results of $T_{1}$ relaxation time measurements are shown in Table 2 below. $\mathrm{T}_{1}$ relaxation curves for ACHN kidney cancer cells are shown in Figure 3. The MRI analysis of control A549 cells showed $\mathrm{T}_{1}$ relaxation time equal to $1025 \mathrm{~ms}$. An increased concentration of lycopene was used to treat the cells allowed to measure lower $T_{1}$ relaxation time. After 24 hours of exposure to the treatment of $20 \mu \mathrm{L}$ of Lycopene, $\mathrm{T}_{1}$ relaxation time decreased by more than $20 \%$ when compared to control untreated cells. The viability of cells treated with lycopene was $96.2 \%, 94 \%, 92$ and $87 \%$, after 24 h treatment with $0 \mu \mathrm{L}, 2.5 \mu \mathrm{L}, 5 \mu \mathrm{L}$ and $20 \mu \mathrm{L}$ of Lycopene respectively. For ACHN cells treated with $0 \mu \mathrm{L}$ (untreated cells), 2,5 $\mu \mathrm{L} / \mathrm{mL}, 5 \mu \mathrm{L} / \mathrm{mL}$ and $20 \mu \mathrm{L} / \mathrm{mL}$ of lycopene, the viability was 98, 94, 92 and $87 \%$ respectively. Analyzing the obtained results, it can be seen that in the case of the A549 lung cancer cells, a decrease in $\mathrm{T}_{1}$ relaxation time with an increase in lycopene concentration was found. The difference between the $T_{1}$ relaxation time of the control sample with pure A549 cells and the sample with $20 \mu \mathrm{L} / \mathrm{mL}$ of Lycopene is $215 \mathrm{~ms}$. In contrast, for the ACHN kidney cancer cells, a $210 \mathrm{~ms}$ difference was observed between the $\mathrm{T}_{1}$ relaxation time of

Table 2. Results of T1 relaxation times of lung cancer cells, lung cancer with the addition of lycopene in various concentrations and DMSO.

\begin{tabular}{|c|c|c|c|c|}
\hline $\begin{array}{c}\text { Control A549 } \\
(\mathrm{ms})\end{array}$ & $\begin{array}{c}\text { A549+ } \\
2.5 \mu \mathrm{mL} \text { Lycopene } \\
(\mathrm{ms})\end{array}$ & $\begin{array}{c}\text { A549+ } \\
5 \mu / \mathrm{mL} \text { Lycopene } \\
(\mathrm{ms})\end{array}$ & $\begin{array}{c}\text { A549+ } \\
20 \mu \mathrm{mL} / \mathrm{mL} \text { Lycopene } \\
(\mathrm{ms})\end{array}$ & $\begin{array}{c}\text { A549+ DMSO } \\
(\mathrm{ms})\end{array}$ \\
\hline $1025 \pm 9$ & $936 \pm 8$ & $904 \pm 9$ & $810 \pm 11$ & $1044 \pm 4$ \\
\hline
\end{tabular}

Tabel 3. Results of T1 relaxation times for kidney cancer cells with the addition of lycopene ( $0 \mu \mathrm{L}$ (untreated cells), $2.5 \mu \mathrm{L}, 5 \mu \mathrm{L}$ and 20 $\mu \mathrm{L}$, respectively) and kidney cancer cells in DMSO.

\begin{tabular}{|c|c|c|c|c|}
\hline $\begin{array}{l}\text { Control } \\
\text { ACHN } \\
(\mathrm{ms})\end{array}$ & $\begin{array}{c}\mathrm{ACHN}+ \\
2.5 \mu \mathrm{L} / \mathrm{mL} \\
\text { Lycopene }(\mathrm{ms})\end{array}$ & $\begin{array}{c}\text { ACHN+ } \\
5 \mu \mathrm{L} / \mathrm{mL} \\
\text { Lycopene }(\mathrm{ms})\end{array}$ & $\begin{array}{c}\text { ACHN+ } \\
20 \mu \mathrm{L} / \mathrm{mL} \\
\text { Lycopene }(\mathrm{ms})\end{array}$ & $\begin{array}{c}\mathrm{ACHN}+ \\
\mathrm{DMSO} \\
(\mathrm{ms})\end{array}$ \\
\hline $679 \pm 7$ & $644 \pm 5$ & $966 \pm 9$ & $469 \pm 10$ & $727 \pm 7$ \\
\hline
\end{tabular}



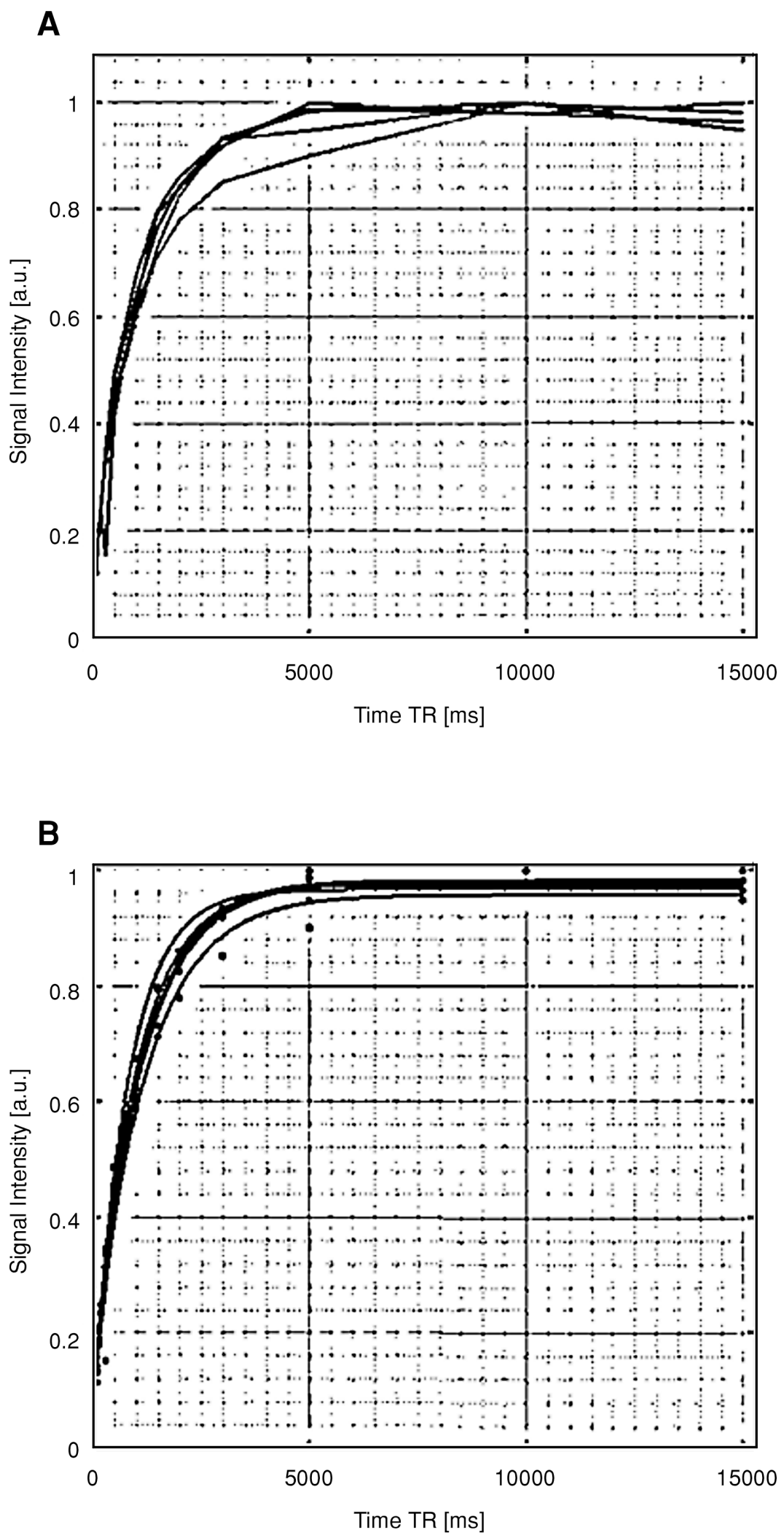

Figure 2. A) $T_{1}$ relaxation time curves for A549 lung cancer cell cultures B) all curves after fitting. The cells were treated with $2.5 \mu \mathrm{L} / \mathrm{mL}, 5.0 \mu \mathrm{L} / \mathrm{mL}, 20 \mu \mathrm{L} / \mathrm{mL}$ lycopene and DMSO. 

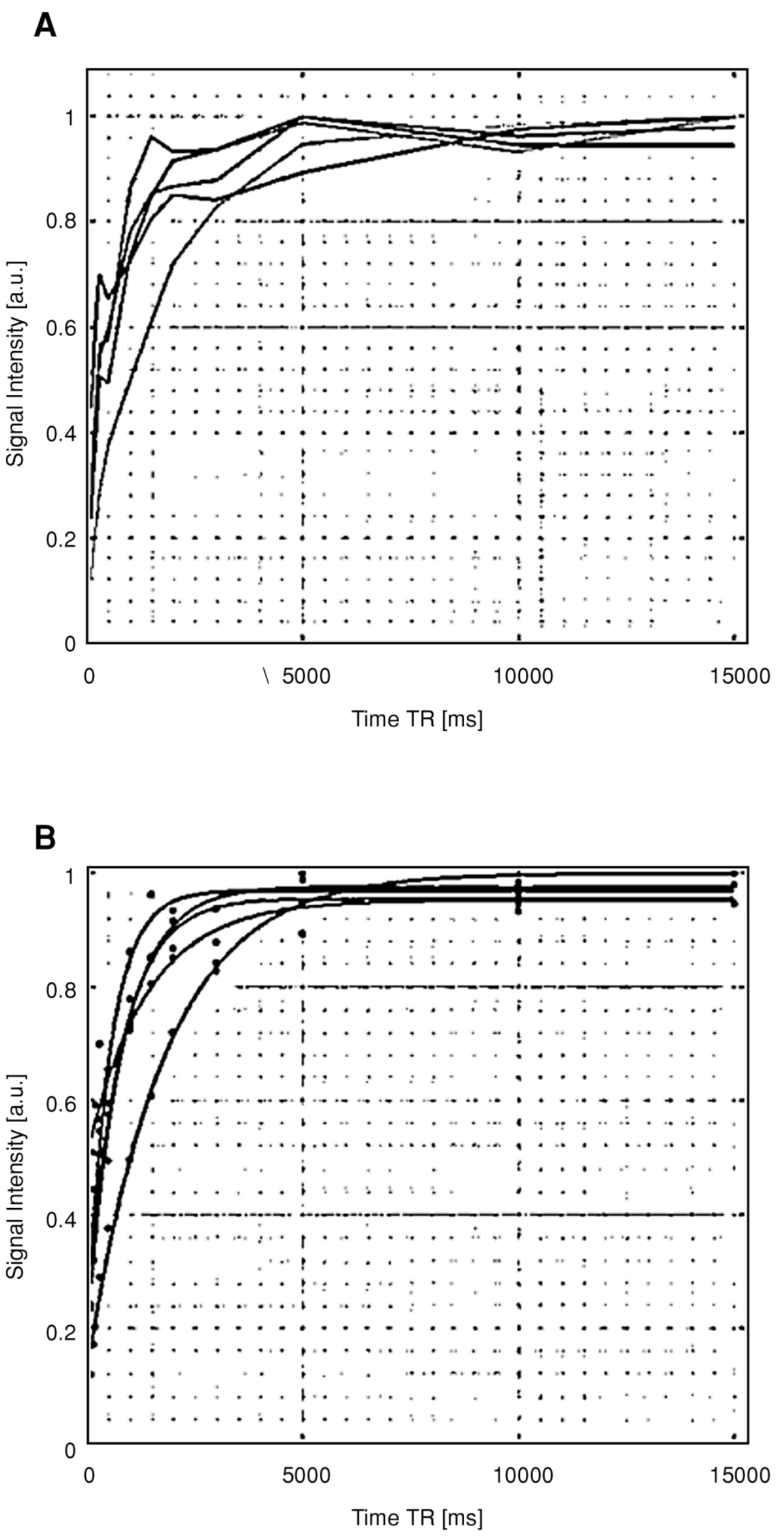

Figure 3. A) $\mathrm{T}_{1}$ relaxation time curves for ACHN kidney cancer cell cultures, B) all curves after fitting. The cells were treated with 2.5 $\mu \mathrm{L} / \mathrm{mL}, 5 \mu \mathrm{L} / \mathrm{mL}, 20 \mu \mathrm{L} / \mathrm{mL}$ lycopene and with DMSO. 
the control sample and the sample with $20 \mu \mathrm{L} / \mathrm{mL}$ of Lycopene.

\section{DISCUSSION}

The addition of various concentrations of lycopene to human cancer cells may induce changes in viability and show the efficacy of lycopene in cancer cell toxicity. In our study we incorporated concentrations of $2.5 \mu \mathrm{L} / \mathrm{mL}, 5 \mu \mathrm{L} / \mathrm{mL}$ and 20 $\mu \mathrm{L} / \mathrm{mL}$ lycopene to lung cancer cell line A549 and kidney cancer cell line ACHN cells for $24 \mathrm{~h}$. In the literature, there are examples of the detection of 0.32 $\mathrm{nmol} / \mathrm{g}$ lycopene in rat lung (12), 120-42 $\mu \mathrm{g} / \mathrm{g}$ lycopene in rat liver (13), 97-47 ng/g lycopene in rat prostate (13), 309-174 ng/g lycopene in the mammary gland and 285-160 $\mathrm{ng} / \mathrm{mL}$ in serum (13) and concentration of lycopene in human plasma in range, 290-350 nmol/L (14, 15). There are many reports about the beneficial effects of lycopene, and we point out the work of Arab et al. on the content of antioxidants in the mucosa of the lung epithelium, which may have a protective effect (16). In addition to this, there are a number of in vitro investigations demonstrating that lycopene is a more potent ROS scavenger than many other dietary carotenoids and other antioxidants, including vitamin $\mathrm{E}$, and the rate constant of quenching singlet oxygen for lycopene is almost double that of $\beta$-carotene (17). Lian et al. in 2007 in his research presented the effect of apo-10'lycopenoic acid on inhibiting the growth of bronchial cancer cells and A549 lung cancer cells in both studies in vivo and in vitro (18). Cheng et al. in 2018 confirmed that ALA inhibits cancer cell motility and angiogenesis by regulating the receptor activated by $\gamma$-peroxisome proliferators (PPAR $\gamma$ ) (19). Whereas Muzandu et al. presented the effect of Lycopene and beta-carotene on cellular modifications that may contribute to the capture of reactive oxygen (ROS) (20). In 1997, Talwar et al. presented the effect of inflammation on the content of antioxidants, among others, lycopene in patients with nonsmall cell lung cancer (NSCLC) (21). In in vivo studies on mice, Jiang et al. tested the effect of lycopene on improving the effect of monoclonal antibody therapy (22). Sheriff et al. performed studies in rats that examined the effect of lycopene in preventing mitochondrial dysfunction during dGalN / LPS-induced FHF (23). Aizawa et al. in 2016, conducted research on the effects of smoking and alleviating these effects with Lycopene supplementation; ferrets were tested in which lung cancer was induced (24). In addition, Satia et al. in their 2009 work described the long-term use of supple- ments, including lycopene with an assessment of the risk of lung cancer (25). Chow and coworkers (26) and Huang and coworkers (27) showed that lycopene can contribute to inhibiting the growth of tumor metastases in in vitro studies. Shareck et al. showed an inverse relationship between the intake of selected carotenoids and vitamins and the risk of lung cancer (28). Cell culture studies have advantages and disadvantages. Firstly, the concentrations of lycopene used are often supraphysiological and the addition of lycopene in different solvents may induce variations between laboratories in terms of efficacy, lycopene concentrations and incorporation into cells. The advantages of our study are a new vision of image interpretation based on intensity differences (contrast) between different cellular qualities. Contrast generation in MRI is one of the main strengths of the method compared to other imaging modalities. Variations of contrast can be achieved by combining different excitation and signal detection times with electromagnetic pulses. The main goal is to choose and adjust the imaging sequence in order to achieve the final desired MRI contrast. The measured MR signal is always determined by multiple effects $\left(\mathrm{T}_{1}-\mathrm{T}_{2}\right.$ relaxation, diffusion, perfusion, susceptibility, etc.) pure. Quantitative $\mathrm{T}_{1}$, data were obtained at 1.5 Tesla on a human scanner. The measured $\mathrm{T}_{1}$, data appear to be accurate. The experiments do not require special MR hardware or software elements. More important is that cells condition can be discussed base on MRI, which still is the most powerful in vivo technique.

\section{Acknowledgments}

Dorota Bartusik-Aebisher acknowledges support from the National Center of Science NCN (New drug delivery systems-MRI study, Grant OPUS-13 number 2017/25/B/ST4/02481).

\section{Conflict of interest}

The authors declare no conflicts of interest.

\section{REFERENCES}

1. Reddy M.K., Alexander-Lindo R.L., Nair M.G.: J. Agric. Food Chem. 53, 9268 (2005).

2. Clinton S.K.: Nutr. Rev. 56, 35 (1998).

3. Bohm F, Tinkler J.H., Truscott T.G.: Nature Medicine 2, 98 (1995).

4. Rao A.V., Agarwal S.: J. Am. Coll. Nutr. 19, 563 (2000).

5. Levy J., Bosin E., Feldmen B., Giat Y., Miinster A., et al.: Nutr. Cancer 24, 257 (1995). 
6. Kim L., Rao V.: J. Med. Food 5, 181 (2002).

7. Chalabi N., Corre L., Mauizis J.C., Bignon Y.J., Bernard-Gallon D.: Eur. J. Cancer 40, 1768 (2004).

8. Park Y.O., Hwang E.S., Moon T.W.: Biofactors 23, 129 (2005).

9. Palozza P., Colangelo M., Simone R., Catalano A., Boninsegna A., et al.: Carcinogenesis 10, 1813 (2010).

10. Guttenplan J.B., Chen M., Kosinska W., Thompson S., Zhao Z., Cohen L.A.: Cancer Lett. 1, 1 (2001).

11. Livny O., Kaplan I., Reifen R., Polak-Charcon S., Madar Z.: J. Nutr. 132, 3754 (2002).

12. Boileau T.W.M., Clinton S.K., Erdman J.W.: J. Nutr. 130, 1613 (2000).

13. Zhao Z., Khachik F., Richie J.P., Cohen L.A.: Proc. Soc. Exp. Biol. Med. 218, 109 (1998).

14. Liu C., Wang X.D., Bronson R.T., Smith D.E., Krinsky N.I., Russell R.M.: Carcinogenesis 21, 2245 (2000).

15. Liu C., Russell R.M., Wang X.D.: J. Nutr. 133, 173 (2003).

16. Arab L., Steck-Scott S., Fleishauer A.T.: Exp. Biol. Med. (Maywood), 227, 894 (2002).
17. Miller N.J., Sampson J., Candeias L.P., Bramley P.M., Rice-Evans C.A.: FEBS Letters 384, 240 (1992).

18. Lian F., Smith D.E., Ernst H., Russell R.M., Wang Y.: Carcinogenesis 28, 1567 (2007).

19. Cheng J., Miao B., Hu K.Q., Fu X., Wang X.D.: J. Nutr. Biochem. 56, 26 (2018).

20. Muzandu K., Ishizuka M., Sakamoto K.Q., Shaban Z., El Bohi K., et al.: Toxicol. Appl. Pharm. 215, 330 (2006).

21. Talwar D., Ha T.K., Scott H.R., Cooney J., Fell G.S., et al.: Am. J. Clin. Nutr. 66: 1283 (1997).

22. Jiang X., Wu H., Zhao W., Ding X., You Q., et al.: Cancer Cell Int. 19, 68 (2019).

23. Sheriff S.A., Shaik Ibrahim S., Devaki T., Chakraborty S., Agarwal S., Perez-Sanchez H.: J. Proteome Res. 16, 3190 (2017).

24. Aizawa K., Liu C., Tang S., Veeramachaneni S., Hu K.Q., et al.: Int. J. Cancer 139, 1171 (2016).

25. Satia J.A., Littman A., Slatore S.G., G. J.A., White E.: Am. J. Epidemiol. 169, 815 (2009).

26. Chow S.K.: J. Nutr. 138, 2289 (2008).

27. Huang C.S., Liao J.W., Hu M.L.: J. Nutr. 138, 538 (2008).

28. Shareck M., Rousseau M.C., Koushik A., Siemiatycki J., Parent M.E.: Front. Oncol. 7, 23 (2017).

( 2020 by Polish Pharmaceutical Society. This is an access article under the CC BY NC license (http://creativecommons.org/licenses/by-nc/4.0/). 